\title{
EFFECTS OF BUFETOLOL AND PROPRANOLOL ON ACTIVE AND PASSIVE MEMBRANE PROPERTIES OF DOG PAPILLARY MUSCLE
}

\author{
Jun INUI and Hiroshi IMAMURA \\ Research Laboratories, Yoshitomi Pharmaceutical Industries, Ltd., \\ Kita-ku, Tokyo 114, Japan
}

Accepted July 1, 1976

\begin{abstract}
Effects of bufetolol and propranolol, adrenergic $\beta$-reccptor blocking and anti-arrhythmic drugs, on active and passive membrane properties of the dog papillary muscle were investigated with microelectrode and sucrose-gap methods. Bufetolol $\left(10^{-5}\right.$ to $\left.10^{-4} \mathrm{~g} / \mathrm{ml}\right)$ and propranolol $\left(10^{-5} \mathrm{~g} / \mathrm{ml}\right)$ significantly decreased the maximum rate of rise of the action potential. The maximum responsive frequency to driving stimulus was decreased in the presence of bufetolol $\left(3 \times 10^{-5} \mathrm{~g} / \mathrm{ml}\right)$ and propranolol $\left(10^{-5} \mathrm{~g} / \mathrm{ml}\right)$, whereas the effective refractory period was not affected. The critical threshold potential was shifted to more positive potential in the presence of the drugs. The passive membrane property, the space constant $(\lambda)$, the time constant $(\tau)$ and the current-voltage relations of the muscle membrane were not significantly altered by the drugs. It is concluded that bufetolol and propranolol suppress the cxcitability of the muscle membrane and this action may be ascribed to the decrease in the sodium conductance $\left(\mathrm{g}_{\mathrm{Na}}\right)$ and to the rise of $\mathrm{g}_{\mathrm{N} i \mathrm{i}}$ onset potential without afteration in the passive membrane property.
\end{abstract}

The effects of anti-arrhythmic drugs on the transmembrane potential of various cardiac tissues have been studied to clarify the mechanism of the action. Many investigators demonstrated that lidocaine as well as quinidine and propranolol suppressed the excitability of the cardiac membrane mainly by reducing the $\mathrm{Na}^{+}$conductance $\left(\mathrm{g}_{\mathrm{Na}}\right)$ and by changing the refractory period, and postulated that the actions might contribute to the anti-arrhythmic effect (1-4). In the cardiac muscle, the propagation of the action potential is achieved by active and passive membrane properties; an inflow of current from the excited fibers to unexcited fibers through the local circuit, the depolarization of membrane up to the critical threshold potential and the initiation of an action potential (5). Therefore, it is also necessary to investigate the effects of anti-arrhythmic drugs on the passive membrane property and the critical threshold potential of the cardiac muscle membrane. Recently, Arnsdorf and Bigger (6) reported that the local circuit of sheep Purkinje fibers became less effective due to the decrease in the space constant $(i)$ in the presence of lidocaine, and suggested that this action of lidocaine contributes to the suppression of the excitability of the membrane at a concentration of the clinical use.

In the present study, the effects of bufetolol, an effective adrenergic $\beta$-receptor blocking and anti-arrhythmic drug (7-9), and propranolol on passive as well as active membrane properties of the dog papillary muscle were studied to determine the mechanism of antialrrhythmic action of the drugs. 


\section{MATERIALS AND METHODS}

Dogs ( 1.5 to $5 \mathrm{Kg}$ ) were anesthetized with pentobarbital sodium ( $30 \mathrm{mg} / \mathrm{kg}$, i.v.). The heart was dissected and the papillary muscle (0.8 to $2 \mathrm{~mm}$ in diameter) of the right ventricle was isolated in Tyrode solution. The solution had the following composition (millimolar concentration): $\mathrm{NaCl} 137 ; \mathrm{KCl} 2.2 ; \mathrm{CaCl}_{2} 1.8 ; \mathrm{MgCl}_{2} 1.1 ; \mathrm{KH}_{2} \mathrm{PO}_{4} 0.5 ; \mathrm{NaHCO}_{3} 12 ;$ glucose 5.5. The papillary muscle was pinned to silicone rubber in a tissue chamber of $10 \mathrm{ml}$ perfused with Tyrode solution at a rate of $10 \mathrm{ml} / \mathrm{min}$. The solution was cquilibrated in the chamber with a mixture of $95 \% \mathrm{O}_{2}+5 \% \mathrm{CO}_{2}$ and was kept at $37-0.5 \mathrm{C}$.

Effects of bufetolol and propranolol on the action potential, maximum responsive frequency to driving stimulus, effective refractory period and conduction velocity.

The papillary muscle was driven by rectangular pulse of $2 \mathrm{~Hz}$ in frequency, $5 \mathrm{msec}$ in duration and twice the threshold, generated by an electronic stimulator (Nihon Kohden, MSE-40) with an isolation unit (Nihon Kohden, MSE-JH). The stimulus electrode consisted of a pair of platinum wires. The microelectrode method was employed to determine the transmembrane potential. The action potential, the maximum rate of rise of action potential (max RR) and developed tension were simultaneously monitored on an oscilloscope (Tektronix, 565). An electrical differentiator with a time constant of $5 \mu \mathrm{sec}$ was used to measure the max RR. The tension development was measured by RCA-5734 under the resting tension of 0.5 to $1 \mathrm{~g}$.

The maximum responsive frequency to driving stimulus was estimated as the maximum frequency at which action potentials would be evoked by the stimuli.

The effective refractory period was determined in the same manner described by Davis and Temte (2). The interval between the preceding driving stimulus and the test pulse which was inserted between two driving stimuli was monitored. The minimum interval in which a propagated action potential was evoked in the muscle fiber was determined to be the effective refractory period (the terminal of effective refractory period).

The conduction velocity was calculated by a conduction time of action potentials between two different cells and by the distance of these cells.

Effects of bufetolol and propranolol were observed after perfusion with Tyrode solution containing each drug for a period of $20 \mathrm{~min}$.

Effects of bufetolol and propranolot on the critical threshold potential, current-voltage relations and cable property

A three compartment chamber as described by Wood et al (10) was employed to polarize the membrane by applied current (the sucrose-gap method). These compartments of the chamber were independently perfused with isotonic $\mathrm{K}_{2} \mathrm{SO}_{4}$ solution, isotonic sucrose solution and oxygenated Tyrode solution (Fig. 1). The papillary muscle was placed over these three compartments. The cathodal polarizing current was applied to drive the preparation ( $1 \mathrm{~Hz}$ in frequency and $10 \mathrm{msec}$ in duration). After $500 \mathrm{msec}$ from the driving stimulus, an anodal or cathodal current in duration of $50 \mathrm{msec}$ was provided. The transmembrane potential was determine by two microelectrodes, one inside and the other outside the mem- 


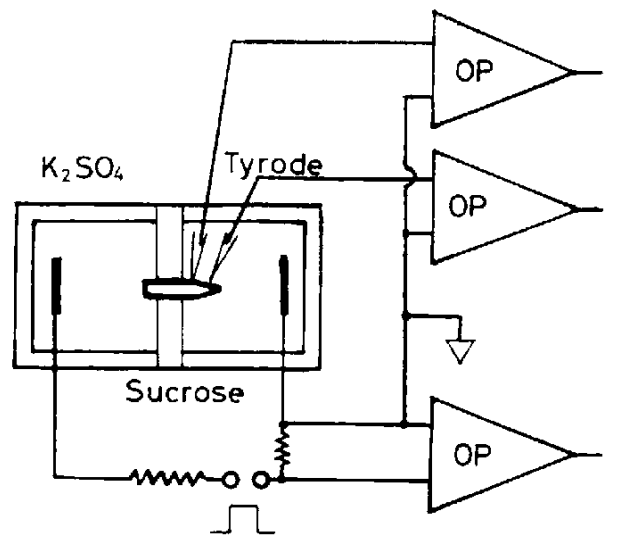

Fig. 1. Schematic diagram of the three compartment chamber and the circuit for the measurement of the transmembrane potential and applying currents. OP represents the operational amplifier. The preparation of the dog papillary muscle is placed over three compartments through holes in two pieces of rubber membrane. The extracellular polarizing current was provided through a resistor of $300 \mathrm{~K} \Omega$. The amount of the current was monitored by a change in potential at a resistor of $1 \mathrm{~K} \Omega$.

brane. These potentials were led to a differential amplifier through pre-amplifiers.

The critical threshold potential was observed as an inflection point of the action potential induced by the minimum cathodal current.

The current-voltage relations were obtained from the relationship between anodal polarizing currents and developed electrotonic potentials, which was graphically illustrated.

The space constant $(\lambda)$ and the time constant $(\tau)$ of the muscle fibers were calculated in the manner described by Kamiyama and Matsuda $(11)$ in order to observe effects of drugs on the cable property of the dog papillary muscle.

Effects of bufetolol $\left(3 \times 10^{-5} \mathrm{~g} / \mathrm{ml}\right)$ and propranolol $\left(10^{-5} \mathrm{~g} / \mathrm{ml}\right)$ on the critical threshold potential, current-voltage relations and cable property were observed after perfusion with Tyrode solution containing each drug for 10 to $30 \mathrm{~min}$

Drugs used were bufetolol hydrochloride (Yoshitomi) and propranolol hydrochloride (Sumitomo). The chemical structure of bufetolol is shown in Fig. 2.

Student's $t$-test was used to determine statistical significance.

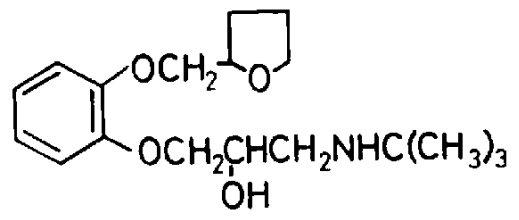

\section{Bufetolol}

FiG. 2. Chemical structure of bufetolol.

\section{RESULTS}

Effects of bufetolol and propranolol on the action potential

The results are summarized in Table 1 . Bufetolol $\left(3 \times 10^{-6} \mathrm{~g} / \mathrm{ml}\right)$ did not influence the action potential of the dog papillary muscle. Bufetolol at higher concentrations than $10^{-5} \mathrm{~g} / \mathrm{ml}$ decreased the max $\mathrm{RR}$ of the action potential significantly. The amplitude and 


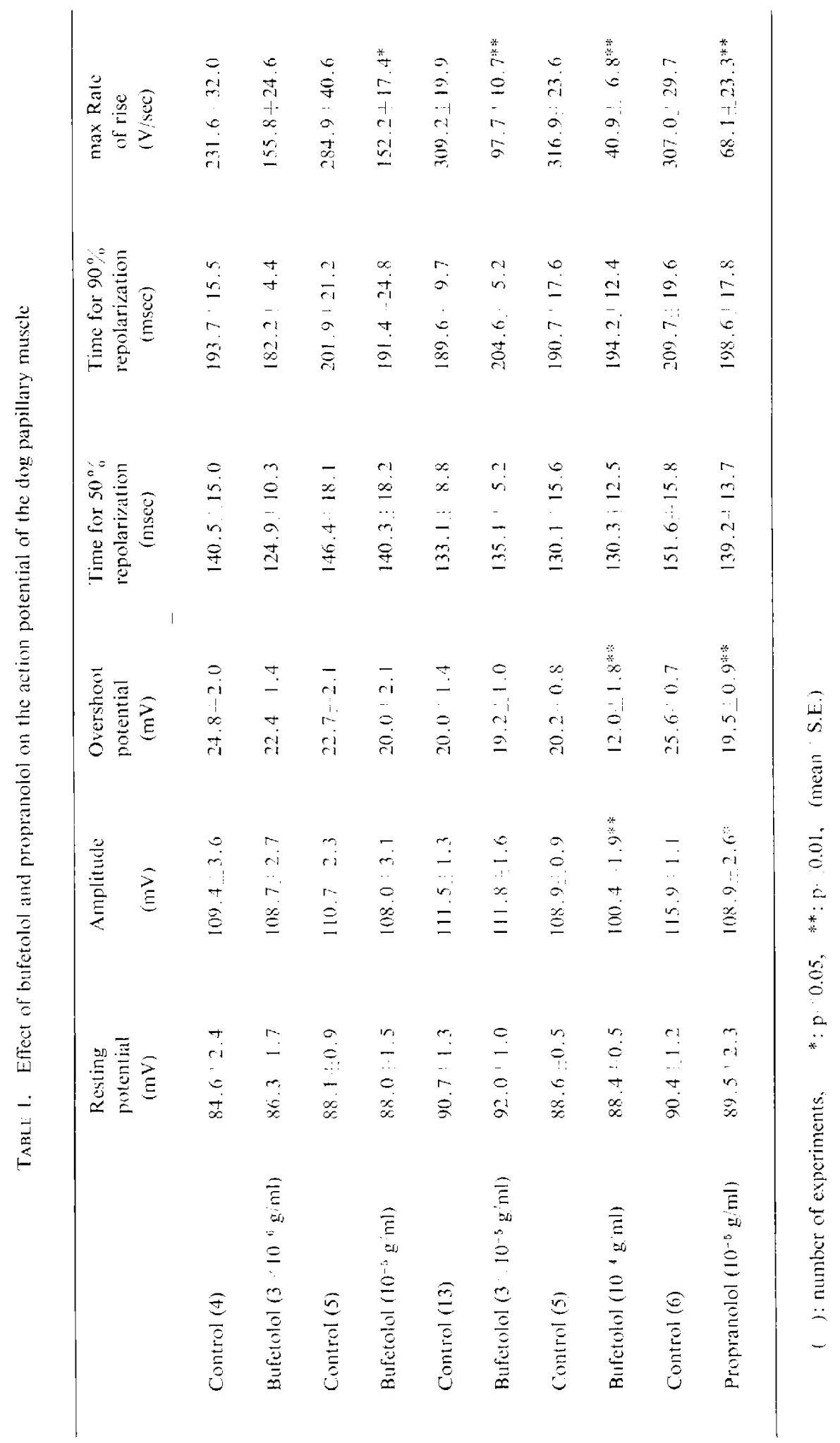


the overshoot potential of the action potential were reduced in the presence of bufetolol $\left(10^{-4} \mathrm{~g} / \mathrm{ml}\right)$. Propranolol $\left(10^{-5} \mathrm{~g} / \mathrm{ml}\right)$ also decreased the max R R, amplitude and overshoot potential, significantly. The resting potential and time for $50 \%$ and $90 \%$ repolarization were not affected by bufetolol and propranolol.

Effects of bufetolol and propranolol on the maximum responsive frequency to driving stimulus

When the frequency of driving stimulus was increased from $2 \mathrm{~Hz}$, the action potential was evoked before full repolarization and the duration of action potential was shortened. An alternative response to stimuli was observed in more rapid stimulation than the maximum responsive frequency to driving stimulus. The maximum responsive frequency to driving stimulus was decreased from $9.12 \perp 1.11 \mathrm{~Hz}$ (mean S.E., $\mathrm{n} \cdots 5$ ) to $5.02 \pm 0.20 \mathrm{~Hz}$ in the presence of bufetolol $\left(3 \times 10^{-5} \mathrm{~g} / \mathrm{ml}\right)$ with a statistical significance, $\mathrm{p}<0.05$. Propranolol $\left(10^{-5} \mathrm{~g} / \mathrm{ml}\right)$ also diminished the frequency from $9.08=0.52 \mathrm{~Hz}(\mathrm{n}=3)$ to $5.05 \pm 0.43 \mathrm{~Hz}$. This difference was statistically significant, $\mathrm{p}<0.01$.

Effects of bufetolol and propranolol on the effective refractory period

The results are summarized in Table 2. Bufetolol and propranolol at concentrations tested had no significant effect on the effective refractory period.

TABLt: 2. Effect of bufetolol and propranolol on the effective refractory period in the dog papillary muscle

\begin{tabular}{|c|c|}
\hline & $\begin{array}{l}\text { Effective refractory period } \\
\qquad(\mathrm{msec})\end{array}$ \\
\hline Control (4) & $170.2 \pm 28.6$ \\
\hline Bufetolol $\left.\left(3: 10^{-6} \mathrm{~g} \mathrm{~m}\right]\right)$ & $162.8=22.2$ \\
\hline Control (5) & $174.1=9.2$ \\
\hline Bufetolol $\left(10^{-i} \mathrm{~g} \mathrm{ml}\right)$ & $168.5-15.2$ \\
\hline Control (5) & $192.4: 8.6$ \\
\hline Bufetolo $\left(3 \cdot 10^{5} \mathrm{~g} \mathrm{ml}\right)$ & $231.0 \ldots 25.4$ \\
\hline Control (5) & $175.2 \therefore 16.2$ \\
\hline Bufetolol $\left(10^{-4} \mathrm{~g}: \mathrm{ml}\right)$ & $207.0-122.2$ \\
\hline Control $(6)$ & $165.2+14.8$ \\
\hline Propranolol $\left(10^{-5} \mathrm{~g} \mathrm{~m} \mathrm{l}\right)$ & $190.2: 7.9$ \\
\hline
\end{tabular}

Effects of bufetolol and propranolol on the conduction velocity

The conduction time was prolonged in the presence of bufetolol $\left(3: 10^{-5} \mathrm{~g} / \mathrm{ml}\right)$ or propranolol $\left(10^{-5} \mathrm{~g} / \mathrm{ml}\right)$. The conduction velocity of the dog papillary muscle was 0.78 $: 0.08 \mathrm{~m} / \mathrm{sec}(\mathrm{n}-5)$. In the presence of bufetolol $\left(3 \div 10^{-5} \mathrm{~g} / \mathrm{ml}\right)$, the conduction velocity was decreased to $0.34-0.01 \mathrm{~m} / \mathrm{sec}(\mathrm{n}:-3)$ with a statistical significance, $\mathrm{p}<0.05$. Propranolol $\left(10^{-5} \mathrm{~g} / \mathrm{ml}\right)$ also reduced significantly the velocity from $0.78+0.08 \mathrm{~m} / \mathrm{sec}(\mathrm{n}=5)$ to $0.36 \pm 0.07$ $\mathrm{m}$ isec, $(\mathrm{p}<0.05)$.

Effects of bufetolol and propranolol on the critical theshold potential, current-voltage relations and cable property

When the depolarization induced by cathodal polarizing current reached the critical 
threshold potential, the action potential was elicited. The critical threshold potential was $-63.5 \ldots 1.3 \mathrm{mV}(\mathrm{n}=20)$ in the dog papillary muscle. In the presence of bufetolol $\left(3 \times 10^{-5}\right.$ $\mathrm{g} / \mathrm{ml})$, the critical threshold potential shifted from $-63.2 \pm 2.3 \mathrm{mV}(\mathrm{n}=-11)$ to $-54.6 \pm 2.0$ $\mathrm{mV}$ with a statistical significance of $\mathrm{p}<0.05$. Propranolol $\left(10^{-5} \mathrm{~g} / \mathrm{ml}\right)$ also changed the critical threshold potential significantly, $\mathrm{p}<0.01$, from $-64.0 \pm 0.7 \mathrm{mV}(\mathrm{n}=9)$ to -49.3 $+1.7 \mathrm{mV}$.

The current-voltage relations did not change in the presence of bufetolol $\left(3 \times 10^{-5} \mathrm{~g} / \mathrm{ml}\right)$ or propranolol $\left(10^{-5} \mathrm{~g} / \mathrm{ml}\right)$. Effects of bufetolol were tested in six preparations and of propranolol in nine preparations. One typical effect of bufetolol on the current-voltage relations is illustrated in Fig. 3.

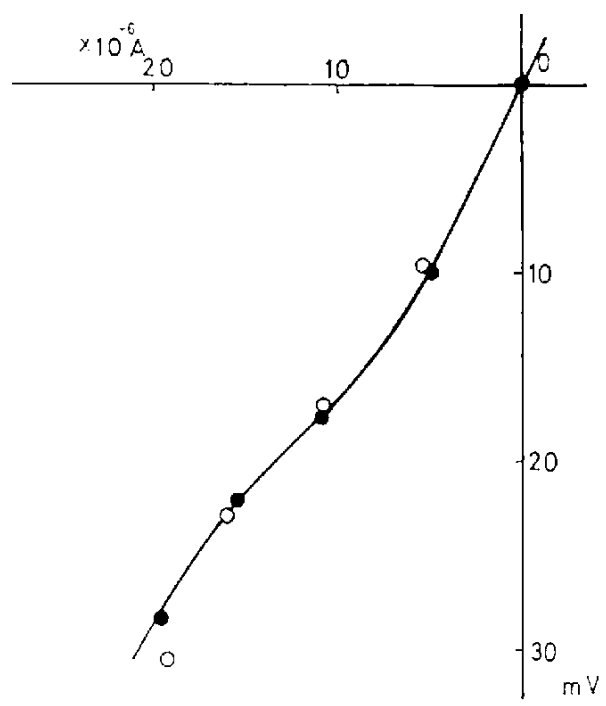

Fig. 3. Effect of bufetolol $\left.\left(3: 10^{-5} \mathrm{~g} / \mathrm{m}\right]\right)$ on the current-voltage relations of the dog papillary muscic membrane. The abscissa represents the amount of anodal current and the ordinate the amplitude of the electrotonic potential. Close circles represent the controls and open circles, data in the presence of bufetolol. The curve was drawn only in control.

The electrotonic potential induced by the anodal polarizing current was decreased in proportion to distance from the sucrose-gap. The relation between logarithm of electrotonic potential and the distance from the sucrose-gap was linear (Fig. 4A). Furthermore, time required for off-response of the electrotonic potential to reach onc half of the amplitude of the potential was increased in direct proportion to distance from the sucrose-gap (Fig. 4B). These results imply that the muscle fibers do indeed have the cable property, such as was demonstrated by Kamiyama and Matsuda (11) and Sakamoto and Goto (12). The value of $\lambda$ was $1.12-0.07 \mathrm{~mm}(n-7)$ and - was $6.52+1.24 \mathrm{msec}(n=7)$. In the presence of bufetolol $\left(3 \times 10^{-5} \mathrm{~g} / \mathrm{ml}\right)$ or propranolol $\left(10^{-5} \mathrm{~g} / \mathrm{ml}\right)$, the muscle fibers also showed the cable property. The values of $\lambda$ and $=$ were not significantly influenced as indicated in Table 3. 

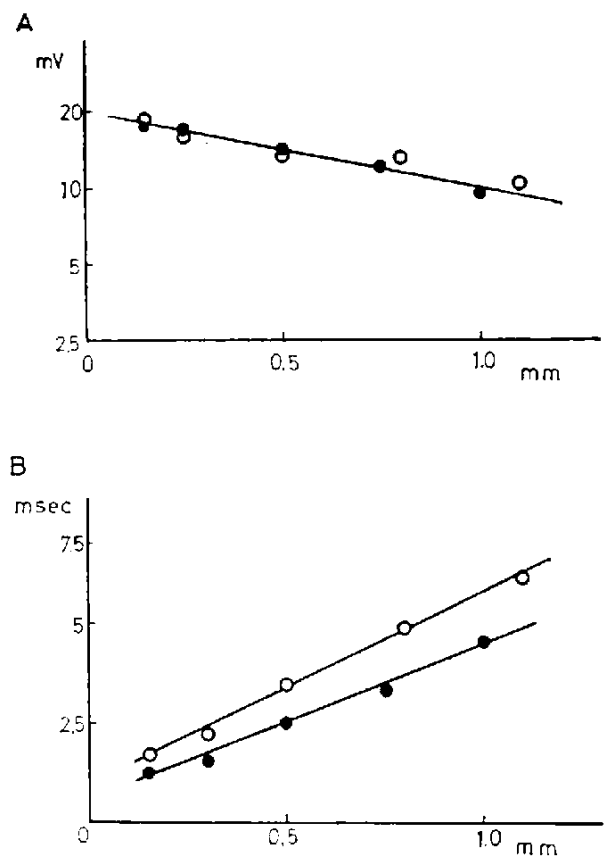

FIG. 4. A demonstration of the decrease in the amplitude of electrotonic potential with an increase in the distance from the sucrose-gap, in A. The ordinate is the logarithm of the amplitude of electrotonic potential and the abscissa the distance. The space constant ( $\lambda$ ) of the papillary muscle is calculated from this graph. The line was drawn only in control. The graph in B is the relationship between the distance from the sucrose-gap (abscissa) and the time required for off-response of electrotonic potential to reach one half of amplitude of the potential (ordinate). The time constant $\Leftrightarrow$ of the muscle fiber is calculated from the slope of this line as described by Kamiyama and Matsuda (11). Closed circles represent the control and open after addition of bufetolol $\left(3 \times 10^{-5} \mathrm{~g} / \mathrm{ml}\right)$ in each graph.

TABLE 3. Effects of bufetolol and propranolol on the space constant $(\lambda)$ and the time constant $(:)$ of the dog papillary muscle

\begin{tabular}{lcr}
\hline & $\begin{array}{c}i \\
(\mathrm{~mm})\end{array}$ & \multicolumn{1}{c}{$\begin{array}{c}\tau \\
(\mathrm{msec})\end{array}$} \\
\hline Control $(4)$ & $1.12 \pm 0.13$ & $5.87 \pm 1.85$ \\
Bufctolol $\left(3 \times 10^{-5} \mathrm{~g} / \mathrm{ml}\right)$ & $1.50=0.34$ & $12.90 \pm 5.55$ \\
Control $(3)$ & $1.21 \pm 0.05$ & $7.39 \pm 1.86$ \\
Propranolol $\left(10^{-5} \mathrm{~g} / \mathrm{ml}\right)$ & $1.23 \doteq 0.17$ & $9.55 \pm 1.32$ \\
\hline
\end{tabular}

( ): number of experiments (mean \pm S.E.)

\section{DISCUSSION}

Bufetolol and propranolol have adrenergic $\beta$-receptor blocking action and antiarrhythmic action (7-9, 13-14). Many investigators have studied the effect of $\beta$-blocking drugs mainly on the action potential in order to elucidate the mechanism of the anti-arrhythmic effect $(2,15,16)$. Nevertheless, since the action potential is elicited and propagated 
by active and passive membrane properties, elfects of the drug on each membrane property should be independently observed to determine the mechanism of the action of the drug. In the present study, the space constant, $\lambda$, the time constant, $-;$, and the current-voltage relations were observed as the passive membrane property, and effects of bufetolol and propranolol on passive as well as active membrane properties were studied.

Bufetolol $\left(10^{-5} \cdot 10^{-4} \mathrm{~g} / \mathrm{ml}\right)$ decreased the max $\mathrm{R} R$ of the action potential without change in the resting potential. This action may be explained by a suppression of $\mathrm{g}_{\mathrm{Na}}$ (17). There was no alteration in the repolarization phase of the action potential at concentrations tested. Therefore, bufetolol may not affect the potassium conductance $\left(\mathrm{g}_{\mathrm{K}}\right)$ and decrease in the max RR may be the main action of bufetolol on the action potential. This action also contributes to a decrease in the conduction velocity induced by bufetolol because the time for charging-up of the membrane capacitance is prolonged by the decrease in the max RR.

Bufetolol significantly diminished the maximum responsive frequency to driving stimulus. This frequency was considered to be an index of the refractory period (18). However, the effective refractory period observed at a driving rate of $2 \mathrm{~Hz}$ was not prolonged in the presence of the drug. Although the precise mechanism of the decrease in the maximum responsive frequency to driving stimulus is unknown, decrease in the $\max R R$ rather than prolongation of the refractory period may be involved with the decrease in the frequency. This action of the drug may prevent or terminate ventricular fibrillation.

The effects of propranolol $\left(10^{-5} \mathrm{~g} / \mathrm{ml}\right)$ were similar to those of bufetolol $\left(3: 10^{-3}-10^{-4}\right.$ $\mathrm{g} / \mathrm{ml}$ ). The present results on propranolol parallel findings by Davis and Temte (2). The mechanism of action of propranolol may be similar to that of bufetolol described above.

The sucrose-gap method was employed in the extracellular polarization, which was effective to alter uniformly the membrane potential by the applied current. The critical threshold potential in this situation was significantly shifted to the more positive potential in the presence of bufetolol and propranolol in dog Purkinje fibers (19). This effect may be attributed to a rise of $\mathrm{S}_{\mathrm{V} a}$ onset potential. Since the membrane resistance did not change as indicated by the experimental result on the current-voltage relations (Fig. 3), a large current is required to depolarize the membrane up to the critical threshold potential in the presence of these drugs. Nevertheless, the current accompanying the action potential which depolarizes the membrane of non-excited fibers can be reduced by bufetolol and propranolol as indicated by the decrease in the max RR. Under these conditions, the initiation as well as the propagation of an cctopic excitation may be adequately suppressed.

The dog papillary muscle possessed the cable property in the presence and absence of bufetolol and propranolol. This property is formulated by the cable equation (20) which is characterized by two constants, $z$ and $z$. The value of $z$ calculated from the present study almost coincides with that previously reported, while the value of $=$ is somewhat larger than that described by Kamiyama and Matsuda (11) and Sakamoto and Goto (12). The values of $\lambda$ and - were not significantly affected by bufetolol and propranolol. These results suggest that the cable property of the dog papillary muscle is not influenced by these drugs. Results seen with bufetolol and propranolol are markedly different from results 
with lidocanine in sheep Purkinje fibers. Lidocaine decreases the value of $\lambda$ and membrane resistance by increasing $g_{K}$. These effects of lidocaine are considered to be effective to suppress the excitability (6). It is suggested that the mode of action of $\beta$-blockers on the excitability of the cardiac tissue is essentially different from that of lidocaine.

In conclusion, bufetolol and propranolol decreased the max RR, maximum responsive frequency to driving stimulus and conduction velocity of the action potential of the dog papillary muscle but had no effect on the effective refractory period. The critical threshold potential was shifted to a more positive potential. The passive membrane property (cable property and current-voltage relations), however, was not significantly influenced by the drugs. Effects of bufetolol and propranolol on the excitability of the dog papillary muscle are attributed to the decrease in $\mathrm{g}_{\mathrm{Na}}$ and the rise of $\mathrm{g}_{\mathrm{Na}}$ onset potential.

Acknowledgenents: Thanks are due to Prof. H. Ozawa for pertinent advice and critical review of the manuscript, and to Prof. Imanaga for relevant discussion.

\section{REFERENCES}

1) Vaugha. Williams, E.M.: Brit. J. Pharmacol. 13, 276 (1958)

2) Davis, L.D. AND Temte, J.V.: Circulation Res. 22, 66I (1968)

3) Davis, L.D. and Temte, J.V.: Circulation Res. 24, 639 (1969)

4) Zetler, G. And Strubelt, O.: Arch. Pharmacol. 271, 335 (1971)

5) HoffMai, B.F. AND CRANefiedd, P.F.: Electrophysiology of the heart, p. 20, McGraw-Hill Book Company, New York (1960)

6) Arnsdorf, M.F. And Biggfr, J.H.: J. Phamacol exp. Ther. 195, 206 (1975)

7) KIMLRA, T., ENDOH, M., TAIRA, N. AND Hasllimoro, K.: Experientia 28, 813 (1972)

8) Hashimoto, K., Klbota, K., Chiba, S. Axd Taira, N. : Experientia 28, 822 (1972)

9) Vakanisiri, M., Imamura, H. and Nakamura, T, : Folia pharmacol. japon. 68, 240 (1972) (in Japanese)

10) WOOb, E.H., He:PPNer, R.L. AND WIIDMANN, S.: Circulation Res. 24, 409 (1969)

11) Kamiyama, A. And Matsuda, K.: Japan. J. Physiol. 16, 407 (1966)

12) SAKamoto, Y. and Goto, M.: Japan. J. Physiol. 20, 30 (1970)

13) Lucchesi, B.R., WiItsitt, L.S. ANd Brown, N.L.: Canad. J. Physiol. Pharmacol. 44, 543 (1966)

14) Parmi.fy, W.W. and Brandinwald, E.: J. Phamacol exp. Ther. 158, 11 (1967)

15) Singh, B.N. and Vaughan Williams, E. M.: Brit. J. Pharmacol. 38, 749 (1970)

16) Sirauss, H.C., Bigger, J.T. and Hofmar, B.F.: Circulation Res. 26, 661 (1970)

17) WeIdManx, S.: J. Physiol. 127, 213 (1955)

18) Dawls, G.S.: Phamacol. Rer. 4, 43 (1953)

19) Shigenobl, K., KamiYama, A., TAkagl, K, aNd Matsuda, K. : Japan. Heart J. 7, 494 (1966)

20) Hodgkin, A.L. A.vd Rushion, W.A.t.: Proc. R. Soc. B. 133, 444 (1946) 